10IKC-173

\title{
LATE METASOMATIC ADDITION OF GARNET TO THE SCLM: OS-ISOTOPE EVIDENCE
}

\author{
Malkovets $^{1 *}$ VG, Griffin ${ }^{2}$ WL, Pearson ${ }^{2}$ NJ, Rezvukhin ${ }^{1}$ DI, O'Reilly² SY, Pokhilenko ${ }^{1}$ NP, \\ Garanin $^{3}$ VK, Spetsius ${ }^{4}$ ZV, Litasov ${ }^{1}$ KD \\ ${ }^{1}$ V.S.Sobolev Institute of Geology and Mineralogy, Novosibirsk, Russia \\ ${ }^{2}$ GEMOC National Key Centre, Macquarie University, Sydney, Australia \\ ${ }^{3}$ Moscow State University, Moscow, Russia: ${ }^{4}$ ALROSA Ltd., Mirny, Russia
}

\section{INTRODUCTION}

Archean cratons are underlain by highly depleted subcontinental lithospheric mantle (SCLM). However, xenolith and xenocryst data suggest that Archean SCLM has been extensively refertilized by metasomatic processes, with the addition of $\mathrm{Fe}, \mathrm{Ca}$, and $\mathrm{Al}$ to depleted protoliths. The distribution of sub-calcic pyropes in the SCLM beneath the Siberian craton suggests that (1) sub-calcic pyropes and diamonds are metasomatic phases in the cratonic SCLM; (2) the distribution of both phases is laterally heterogeneous on relatively small scales and related to ancient structural controls (Malkovets et al., 2007). More advanced metasomatism of sub-calcic garnets leads to formation of lherzolitic pyropes varying widelt in $\mathrm{Cr}$ and $\mathrm{Ca}$ contents along the lherzolitic trend (Griffin et al., 1999b; Burgess et al., 2004). However, the timing of such metasomatic events and formation of pyropes in cratonic mantle is still unclear.

Conventional $\mathrm{Sr}$ and $\mathrm{Nd}$ methods of isotope dating have failed to give any reasonable ages for garnet-bearing lherzolites. Sr and Nd isochron ages calculated for Cpx and Gar typically give ages close to the eruption age of the host magma. Bulk Earth Sm-Nd model ages of harzburgitic subcalcic pyropes from the Udachnaya pipe vary from Paleoproterozoic to Archean (1.7-3.0 Ga; Pearson et al., 1995). Whole-rock Re-Os dating of peridotites reflects the mixing of different generations of sulfides and the interpretation of such data in terms of depletion ages therefore becomes ambiguous (Alard et al,. 2000, 2002; Griffin et al., 2002).

Sulfides, which are commonly found as an accessory mineral in mantle peridotites, usually have high concentrations of highly siderophile elements (HSE). Recent developments in the in situ analysis of sulfide phases made them available for in situ Re-Os dating (Pearson et al., 2002, Griffin et al., 2002, Alard et al., 2002). To In situ Re-Os dating of sulfides inclusions in olivine xenocrysts from the Udachnaya pipe gave model ages between 2.5 and $3.6 \mathrm{Ga}$ with majority being older than $2.8 \mathrm{Ga}$ (Griffin et al., 2002). To constrain the timing of the deposition of pyrope in the Siberian cratonic lithosphere we have picked pyropes with sulfide inclusions from heavy concentratse of kimberlites for in situ Re-Os dating.

Here we present the results of in situ Re-Os study of individual sulfide grains enclosed in xenocrystic pyropes from the middle-Paleozoic diamondiferous Internationalnaya kimberlite pipe, Malobotuobia field, Siberian craton, Yakutia.

\section{GEOLOGICAL BACKGROUND}

The Internationalnaya pipe is situated in the middle Paleozoic Malobotuobia kimberlite field in the southern part of the Yakutian diamondiferous province. Malobotuobia field 
consist of seven kimberlite bodies, of which four contain diamonds in economic quantities - XXIII Party Congress, Mir, Internationalnaya and Dachnaya pipes. $\mathrm{U} / \mathrm{Pb}$ dating of zircons from $\mathrm{Mir}$ pipe gives a middle Paleozoic age for kimberlite intrusion in the Malobotuobia field (Davis et al., 1980; Griffin et al., 1999a). Fresh mantle xenoliths occur in the Mir pipe, while in the Internationalnaya pipe most of them are completely altered. Diamond inclusion studies show an overwhelming preponderance of peridotitic over eclogitic parageneses (Sobolev et al., 1997).

Kimberlites of the Malobotuobia field intruded within the Archean Magan terrane of the Siberian Platform. The Archean basement is covered by a thick section of Paleozoic sediments. Sparse Nd model ages for crustal xenoliths from the Mir pipe and basement rocks from the drillholes around the Malobotuobia field suggest crustal formation from 2.6 to $3.45 \mathrm{Ga}$, with a major metamorphic event $>2.6 \mathrm{Ga}$, and minor magmatic events associated with craton amalgamation around 1.9-2.0 Ga (Rosen et al., 1994; Smelov et al., 2007).

\section{SAMPLE DESCRIPTION}

\section{Pyropes}

More than 3000 pyropes from the $-4+2$ sieve class $\mathrm{mm}$ were carefully examined under binocular microscope to find grains with sulfide inclusions. 110 pyrope grains with single or multiple sulfide inclusions have been selected for this study. They were set in individual epoxy mounts and polished to expose sulfide inclusions, which vary in size from 25 to 70 microns.

\section{ANALYTICAL METHODS}

Major element analyses of the sulfide phases and the host pyropes were done on a JEOL Superprobe at VS Sobolev Institute of Geology and Mineralogy SB RAS, Novosibirsk, Russia and on a CAMECA SX100 at GEMOC National Key Centre, Macquarie University, Sydney, Australia. The distribution of elements was mapped using energy-dispersive detectors INCA 350 attached to a LEO $1430 \mathrm{VP}$ electron microscope (Novosibirsk) and LINK attached to the CAMECA SX100 (Sydney). Re-Os isotope data have been collected in situ using a Merchantek LUV266 laser microprobe attached to a $\mathrm{Nu}$ Plasma multi-collector ICPMS. The analytical and calibration procedures and the applied corrections as well as reproducibility of analyses of standard materials are described in detail by Pearson et al. (2002).

\section{MINERALOGY}

\section{Pyropes}

The compositions of the pyropes with sulfide inclusions are presented in Figure 1. All are Cr-bearing ( $>2 \mathrm{wt.} \%)$ and thus classified as peridotitic. Most fall into the lherzolitic field, indicating equilibrium with both clinopyroxene and orthopyroxene. Pyrope Int-92 with high $\mathrm{CaO}$ (10.65 wt.\%) and low $\mathrm{Cr}_{2} \mathrm{O}_{3}$ (3.44 wt.\%) represents a wehrlitic paragenesis (i.e. equilibrium with clinopyroxene only). Ten pyropes classify as sub-calcic or G10 (i.e. equilibrium with orthopyroxene only), similar to those found as inclusions in diamonds (Sobolev et al., 1973).

\section{Sulfides}

Sulfide images show that most sulfides consist of several phases varying in $\mathrm{Fe}, \mathrm{Ni}, \mathrm{Cu}$, and $\mathrm{S}$ contents. Based on the morphology of the sulfide inclusions, their internal structure and the compositions of coexisting phases we interpret these as low-temperature assemblages that exsolved from single high-temperature solid solutions during cooling subsequent eruption of the host kimberlite. 


\section{0 $^{\text {th }}$ International Kimberlite Conference, Bangalore - 2012}

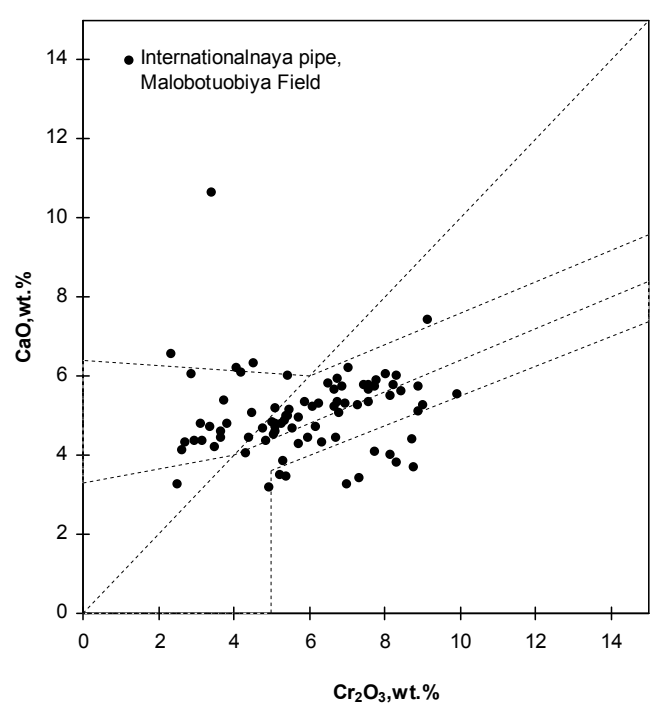

Figure 1. $\mathrm{Cr}_{2} \mathrm{O}_{3}$ vs $\mathrm{CaO}$ in pyropes with sulfide inclusions. Fields after Sobolev et al. (1973).

\section{RE-OS DATA}

Re-Os isotopic compositions have been determined by laser ablation MC-ICPMS for 105 sulfides included in pyropes. Most analysed sulfides $(\sim 84 \%)$ have very low ${ }^{187} \mathrm{Re} /{ }^{188} \mathrm{Os}$ ratios $(<0.07)$. Modeling by Griffin et al. (2002) suggested that sulfides with ${ }^{187} \mathrm{Re} /{ }^{188} \mathrm{Os}<0.07$ are unlikely to have been disturbed any metasomatic events.

$\mathrm{T}_{\mathrm{CHUR}}$ and $\mathrm{T}_{\mathrm{RD}}$ model ages for most sulfides are $>2.2 \mathrm{Ga}$ (Figure 2 and 3 ). $\mathrm{T}_{\text {CHUR }}$ ages fall mainly between 2.2 and $3.2 \mathrm{Ga}( \pm 0.03 \mathrm{Ga}$, mean 2s analytical uncertainty; Figure 2).

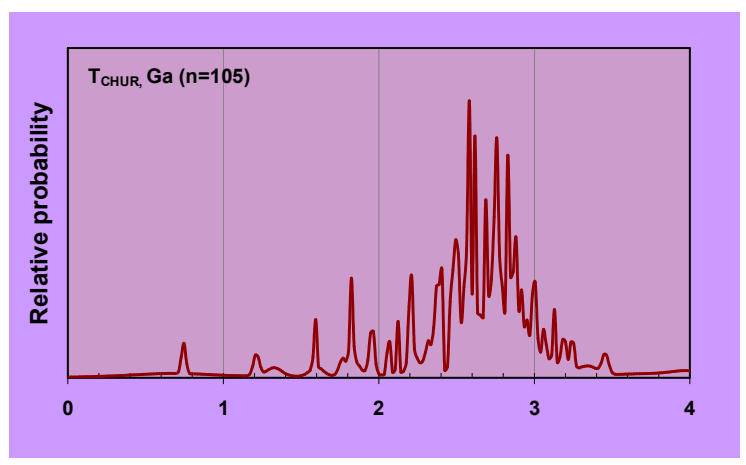

Figure 2. Cumulative probability diagram of $\mathrm{T}_{\text {CHUR }}$ model ages (model parameters of Shirey and Walker, 1998).
Re-depletion ages (TRD) als fall between 2.2 and $3.0 \mathrm{Ga}( \pm 0.03 \mathrm{Ga}$, mean $2 \mathrm{~s}$ analytical uncertainty; Figure 3). 10 to $15 \%$ of the sulfides give younger TRD down to $600 \mathrm{Ma}$.

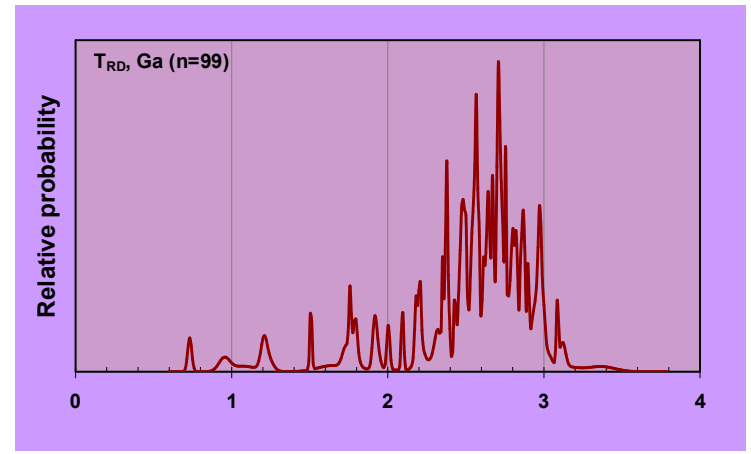

Figure 3. Cumulative probability diagram of $\mathrm{T}_{\mathrm{RD}}$ model ages (defined by Walker, 1989).

In cumulative probability plots one mode with the maximum at $2.7 \mathrm{Ga}$ is evident for both $\mathrm{T}_{\text {CHUR }}$ and $\mathrm{T}_{\mathrm{RD}}$ ages. This age correlates with the age of the major crustal metamorphic event $\left(\mathrm{M}_{1}\right)$ in the Magan and the Daldyn terrains.

\section{DISCUSSION}

There are few published Re-Os data for sulfides from Siberian xenoliths (Pearson et al., 1995) and xenocrysts (Griffin et al., 2002). Both of these papers deal with samples from the Udachnaya pipe, in Daldyn kimberlite field which is situated $700 \mathrm{~km}$ north of the Malobotuobia field. However, Udachnaya is the only pipe with which we can compare our data.

$\mathrm{T}_{\text {CHUR }}$ model ages for sulfides from olivine xenocrysts from Udachnaya pipe (Griffin et al., 2002) and our $T_{\text {CHUR }}$ model ages for sulfides from pyrope xenocrysts from Internationalnaya pipe are plotted for comparison on Figure 4.

Our previous study of sulfide inclusions in megacrystic olivines from the Udachnaya pipe suggests that most of the SCLM beneath the Daldyn kimberlite field formed at 3-3.5 Ga, and that lithosphere formation culminated at ca 2.9 $\mathrm{Ga}$ (the biggest peak at the Figure 4) (Griffin et al., 2002). 


\section{0 $^{\text {th }}$ International Kimberlite Conference, Bangalore - 2012}

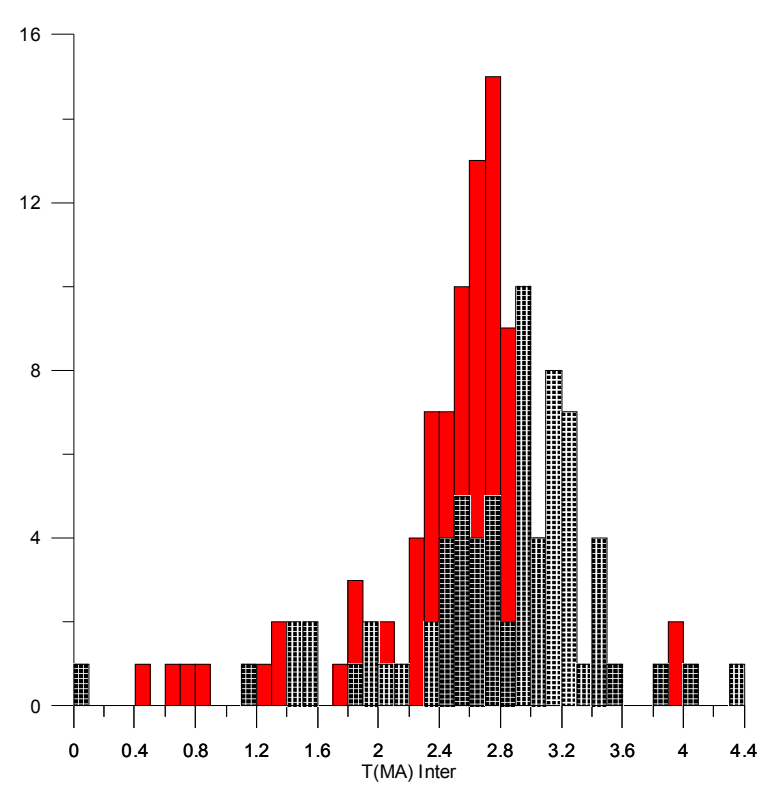

Figure 4. Hystogram of $T_{\text {CHUR }}$ model ages for sulfides included in pyrope xenocrysts from the Internationalnaya pipe (red) and in olivine xenocrysts from the Udachnaya pipe (white) (model parameters of Shirey and Walker, 1998).

Our new data suggest that refertilization of the depleted SCLM and the introduction of Crpyrope garnet occurred between 2.2 and $3.0 \mathrm{Ga}$; little garnet was present before $3 \mathrm{Ga}$. Pyropes with young sulfides (between $\sim 1.7$ and $\sim 2.2 \mathrm{Ga}$ ) may have crystallized in response to metasomatism during the amalgamation of the Siberian craton.

\section{References}

Alard O., Griffin W. L., Lorand J. P., Jackson S. E. and O'Reilly S. Y. (2000) Non-chondritic distribution of the highly siderophile elements in mantle sulfides. Nature 407, 891.

Alard O., Griffin W. L., Pearson N. J., Lorand J.-P. and O'Reilly S. Y. (2002) New insights into the $\mathrm{Re}-$ Os systematics of subcontinental lithospheric mantle from in situ analysis of sulfides. Earth Planet. Sci. Lett. 203, 651.

Burgess, S.R., Harte, B. (2004) Tracing lithosphere evolution through the analysis of heterogeneous G9-G10 garnets in peridotite xenoliths, II: REE chemistry. Journal of Petrology 45, 609-634.
Davis, G.L., Sobolev, N.V., Khar'kiv, A.D. (1980) New data on the age of yakutian kimberlites obtained by the uranium-lead method on zircons. Dokl. AN SSSR 254, 175-180.

Griffin, W. L., C. G. Ryan, F. V. Kaminsky, S. Y. O'Reilly, L. M. Natapov, T. T. Win, P. D. Kinny, and I. P. Ilupin (1999a) The Siberian Lithosphere Traverse: Mantle terranes and the assembly of the Siberian Craton, Tectonophysics, 310, 1-35, 1999.

Grifûn, W.L., Shee, S.R., Ryan, C.G., Win, T.T., Wyatt, B.A. (1999b) Harzburgite to lherzolite and back again: metasomatic processes in ultramaûc xenoliths from the Wesselton kimberlite, South Africa. Contributions to Mineralogy and Petrology 134, 232-250.

Malkovets, G., Grifûn, W.L., O'Reilly, S.Y., Wood, B.J. (2007) Diamond, subcalcic garnet and mantle metasomatism: kimberlite sampling patterns deûne the link. Geology 35, 339-342.

Pearson D. G., Shirey S. B., Carlson R. W., Boyd F. R., Pokhilenko N. P., and N. Shimizu (1995) Re$\mathrm{Os}, \mathrm{Sm}-\mathrm{Nd}$, and $\mathrm{Rb}-\mathrm{Sr}$ isotope evidence for the thick Archaean lithospheric mantle beneath the Siberian craton modified by multistage metasomatism, Geochim. Chosmochim. Acta, 59, 959 - 977.

Pearson N. J., Alard O., Griffin W. L., Jackson S. E. and O'Reilly S. Y. (2002) In situ measurement of Re-Os isotopes in mantle sulfides by laser ablation multicollector-inductively coupled plasma mass spectrometry: analytical methods and preliminary results. Geochim. Cosmochim. Acta 66, 1037.

Rosen, O. M., K. C. Condie, L. M. Natapov, and A. D. Nozhkin (1994) Archean and early Proterozoic evolution of the Siberian Craton: a preliminary assessment, in Archean Crustal Evolution, edited by K. Condie, pp. 411-459, Elsevier Sci., New York.

Shirey S. B. and Walker R. J. (1998) The Re-Os isotope system in cosmochemistry and hightemperature geochemistry. Annu. Rev. Earth Planet. Sci. 26, 423-500.

Smelov A. P. and Timofeev V. F. (2007) The age of the North Asian Cratonic basement: an overview. Gondwana Res. 12, 279-288.

Sobolev, N., Kaminsky, F., Grifûn, W., Yeûmova, E., Win, T., Ryan, C., Botkunov, A. (1997) Mineral 
inclusions in diamonds from the Sputnik kimberlite pipe, Yakutia. Lithos 39, 135-157.

Sobolev, N.V., Lavrent'ev, Y.G., Pokhilenko, N.P., Usova, L.V. (1973) Chrome-rich garnets from the kimberlites of Yakutia and their paragenesis. Contributions to Mineralogy and Petrology 40, 3952. 